\title{
VÝVOJ DŮCHODOVÉHO POJIŠTĚNÍ NA ÚZEMÍ DNEŠNÍ ČR OD POČÁTKU 20. STOLETÍ PO SOUČASNOST ${ }^{1}$
}

\author{
MILAN HRDÝ
}

\begin{abstract}
The Development of Pension Insurance in the Territory of Today's Czech Republic from the Beginning of the 20th Century to the Present

The article deals with the problems of pension insurance in the territory of today's Czech Republic from the beginning of the 20th century to the present. The main principles of the development of the pension system in the given period were identified and the analysis was performed mainly in terms of the personal and material scope of insurance, insurance obligations, and briefly in terms of the organizational security of the pension system as well. This analysis was carried out in four selected periods. At the end of the article, the relevant findings from this historical development are summarized and with their use the author's own proposal for the development of the pension insurance system in the Czech Republic in the future is presented.
\end{abstract}

Keywords: pension system; historical development; analysis; Czech Republic

Klíčová slova: důchodový systém; historický vývoj; rozbor; Česká republika

DOI: $10.14712 / 23366478.2021 .44$

\section{1. ÚVOD}

Cílem tohoto článku je prezentovat klíčové aspekty vývoje důchodového systému na území ČR od začátku 20. století po současnost a na základě této identifikace a rozboru vyvodit př́íslušná doporučení pro vývoj důchodového pojištění v ČR do budoucnosti.

Identifikace vývoje penzijního pojištění je založena na hodnocení jednotlivých právních kategorií a jednotlivých parametrů v rámci příslušných vymezených relativně homogenních období. Posuzován je především osobní a věcný rozsah pojištění, pojištovací povinnosti a stručně také organizační zabezpečení důchodového pojištění. Teoretická východiska jsou založena na stručné analýze vybrané literatury, která se vybranými aspekty důchodového pojištění na území dnešní Č̉ zabývala. Mưžeme zmínit např. pu-

1 Tento článek vznikl v rámci projektu UNCE/HUM/034 Závislá práce v 21. století - otázky a výzvy na Právnické fakultě Univerzity Karlovy. 
blikaci prof. Lukáše, ${ }^{2}$ která analyzuje právo sociálního zabezpečení v období začátku první republiky s odkazy na právo sociálního zabezpečení Rakouska-Uherska. I když v rámci práva sociálního zabezpečení je realizováno především nemocenské a úrazové pojištění, velmi zajímavé informace lze získat také ohledně důchodového pojištění. Za zmínku stojí určitě analýza vztahu sociální profylaxe v pojišt’ování invalidním a penzijním a profylaxe $\mathrm{v}$ pojišstění nemocenském a úrazovém. Podstata sociální politiky v období první republiky a její východiska jsou řešena v zajímavé publikaci ${ }^{3}$ prof. Karla Engliše z Právnické fakulty Masarykovy univerzity v Brně (toho času guvernéra Národní banky Československé). Engliš zmiňuje tzv. solidaristické právo - stát nutí individua, aby jednala jinak, než kdyby se rrídila pouze svými osobními zájmy. ${ }^{4}$ Vedle aktivity normotvorné hraje důležitou roli také aktivita hospodářská, opatřování prostředků pro solidaristické hospodářství vede $\mathrm{k}$ vyrovnávání důchodů na základě příslušných donucovacích norem. Donucování je realizováno nejčastěji prostřednictvím daní. Je třeba si uvědomit, že pod pojmem důchody zde rozumíme př́ijmy obyvatel, tj. jedná se zde především o ekonomický výraz. K realizaci sociální politiky je tak nezbytné opatřování prostředků, které se může dle Engliše dít negativním působením k vyrovnávání důchodů a negativním působením $\mathrm{k}$ vyrovnávání majetku. ${ }^{5}$ Vyrovnávání důchodů se děje především snižováním důchodů nadměrných a vyšších a zvláštním zdaněním majetku. Engliš si velmi dobře uvědomoval, že pro kvalitní sociální právo jsou nezbytné nejen kvalitně zpracované právní normy, ale také opatření prostředků především z důchodů a majetku těch bohatších ve společnosti na základě př́slušné životní míry. Souvisí to s rozdělováním plodů práce (národního produktu). Tento přístup opodstatňuje současné hledání zdrojů pro financování starobních důchodů na základě vyššího zdanění firem či nemovitostí, podle př́stupu různých politických stran. Nejedná se tedy o komunistický výmysl, jak se to někteří politici u nás snažili prezentovat (viz další text, např. zkušenosti prof. Tomeše), ale tato problematika byla řešena již v první polovině dvacátého století, a to včetně Beveridgeovy sociální reformy ve Velké Británii během druhé světové války a těsně po ní. Problematiku sociální politiky Engliš rozděloval na politiku všeobecnou a zvláštní, přičemž ve všeobecné politice jde o rozdělování plodů práce (národního produktu) a také břemene práce samotné podle zásad osobní solidarity. ${ }^{6}$ Sociální politika zvláštní se pak zabývá podstatou a problémem jednotlivých sociálních tř́íd a rozpadá se na sociální politiku dělnickou, středostavovskou, chudinskou a spotřebitelskou. ${ }^{7}$ Klíčový význam př́spěvku Engliše k problematice sociální politiky včetně politiky důchodové má uvědomění si velmi těsné vazby práva a ekonomie, kdy precizně formulované právní normy v oblasti sociálního pojištění se neobejdou bez důsledné ekonomické analýzy toho, jak velké bohatství společnosti je $\mathrm{k}$ dispozici pro přerozdělení pro účely kvalitního sociálního zabezpečení. Klíčový zákon týkající se prvorepublikového důchodového pojištění, tj. zákon o pojištění zaměstnanců pro př́ípad nemoci, invalidity a stáŕí,

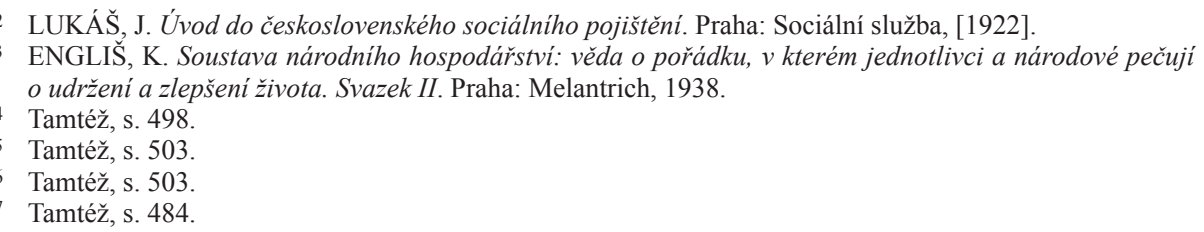


v aktuálním znění, byl analyzován v publikaci autorů Gallase a Janoštíka, ${ }^{8}$ přičemž rozbor byl proveden jak z hlediska hmotněprávního, tak i z hlediska procesněprávního. Sociální pojištění je vymezeno jako souborný název pro devět rozdílných druhů pojištění, a to proti přechodné nezpůsobilosti ku práci způsobené nemocí, mateřstvím, nezaviněnou nezaměstnaností (celkem tři), dále proti trvalé nezpůsobilosti ku práci způsobené úrazem, invaliditou a stářím (další tři) a proti úplnému zničení osobnosti způsobené smrtí, pokud má smrt za následek újmu finanční, s tím, že existoval určitý vývoj sociálního pojištění, který nejprve kladl důraz na pojištění úrazové a nemocenské. Byly vymezeny příslušné zásady, na kterých tehdejší pojištění zaměstnanců stálo. Mezi tyto základní zásady patřila zejména myšlenka pojištění, a nikoliv zaopatření, zaměření na osoby nesamostatně činné, dále pak ponechání samostatného pojištění horníků a také dlouhodobost dávek invalidního a starobního pojištění a existence tzv. čekací doby u tohoto druhu pojištění. ${ }^{9}$ Značná pozornost je také věnována nové úpravě pojišt'ovacího soudnictví, které bylo na tehdejší dobu velmi vyspělé. Tato vyspělost spočívala zejména v samotné existenci pojišt'ovacího soudu, což nebylo zdaleka běžné ani ve vyspělých zemích, dále pak v jasné identifikaci působnosti pojišt'ovacího soudu a řízení u něho a také v oblasti opravných prostředků týkající se především odvolání proti rozsudkům včetně role Vrchního pojištovacího soudu.

Na konci první republiky vznikla zajímavá publikace ${ }^{10}$ analyzující mimo jiné i invalidní a starobní pojištění dělníků. Nejprve je analyzován velmi stručně vývoj sociálního pojištění na území tehdejší ČSR s dưrazem na to, že smysl sociálního pojištění spočívá v tom, že ,pracující vrstvy národa, jejímž jediným kapitálem jest jejich pracovní síla, byly alespoň částečně chráněny proti rizikưm čekajícím na každého člověka, jako jest nemoc, invalidita, stář́, úraz a smrt “. ${ }^{11}$ Analyzována je rovněž otázka vynětí osob z pojištění invalidního a starobního, přičemž je konstatováno, že se jedná o všechny osoby, které jsou vyňaty z pojištění nemocenského. ${ }^{12}$ Pro účely důchodového pojištění mělo význam také vymezení zaměstnání př́iležitostného. Důsledně byly odlišovány pojmy zaměstnání vedlejšího a př́ležitostného, přičemž autor publikace odkazuje na judikaturu Nejvyššího správního soudu, který příležitostné zaměstnání vymezil jako druh smluvního závazku, který pro svoji nahodilost a krátkodobost netvoří řádný zdroj příjmů pracující osoby. ${ }^{13}$ Poměrně velká část publikace je věnována také oblasti procesního práva v oblasti sociálního pojištění, ze které jasně vyplývá, že oblast procesního práva sociálního zabezpečení v období první ČSR byla na velmi vysoké úrovni, a to včetně systému odvolacích řízení.

\footnotetext{
8 GALLAS, J. - JANOŠTÍK, F. Výklad k zákonu o pojištění zaměstnanců pro př́pad nemoci, invalidity a stáři ve zněni novely ze dne 8. listopadu 1928, čís. 184 Sb. z. a n. 4. úplně přepr. vyd. Praha: nákladem Sdružení úředníků a zřízenců československých sociálně-pojištovacích ústavů, 1929.

9 Tamtéž, s. 20-22.

10 MIMRA, S. Systém nemocenského, invalidního a starobního pojištěni délníkủ podle zákona o sociálním pojištění. Praha: nákladem Čs. ústředí nemocenských pojištoven, 1936.

11 Tamtéž, s. 7.

12 Tamtéž, s. 24.

13 Tamtéž, s. 23.
} 
V období socialismu vznikla zajímavá studie ${ }^{14}$ týkající se problematiky důchodového věku žen, která velmi podrobně analyzuje a zdůvodňuje nutnost dř́vějšího odchodu žen do starobního důchodu. Publikace vychází nejprve z analýzy tehdejš́́ho stavu věku odchodu do starobního důchodu žen, přičemž je konstatováno, že kromě socialistických zemí, kde je nižší důchodový věk žen považován za určitou vymoženost systému, se i stále více zemí kapitalistických přiklání $\mathrm{k}$ věkové diferenciaci při odchodu do důchodu žen. Za klíčový diferenciační prvek je považován mimo jiné počet vychovaných dětí. Z pohledu právních východisek pro další analýzy je třeba vyzdvihnout především jasnou snahu o poměrně precizní a sofistikované zdůvodnění nižšího věku odchodu do důchodu. Toto zdůvodnění se opírá o zkušenosti z bývalého Sovětského svazu, Velké Británie a tehdejšího Československa. Prameny z bývalého Sovětského svazu, které však nejsou v publikaci blíže specifikovány, zdůvodňují nižší důchodový věk žen tím, že ženy mají výrazně nižší věk invalidizace než muži, že se u žen dříve začíná ztrácet schopnost pracovat, a také byly zmíněny i tzv. politické ohledy, kdy si socialistická společnost váží náročné role žen a chce jim umožnit dřívější odchod do starobního důchodu. ${ }^{15}$ Prameny z Velké Británie se opírají o kontext Beveridgeovy zprávy, ${ }^{16}$ kdy starobní důchod manželky doplňuje starobní důchod manžela, a je vhodné, pokud oba manželé budou odcházet do důchodu ve stejné době, a protože manželka je zpravidla o několik let mladší, měla by tedy odcházet do důchodu v nižším věku. ${ }^{17} \mathrm{~V}$ tehdejším Československu se vycházelo z toho, že žena má specifické postavení ve společnosti a že společnost nemůže převzít všechny povinnosti ženy, které má v domácnosti a rodině, a dále pak bylo zdůrazňována také skutečnost, že porody a následná výchova dětí vyžadují přestávky v pracovní činnosti ženy a následně větší nároky na její organismus. ${ }^{18} \mathrm{Za}$ pozornost stojí rozhodně poměrně sofistikovaná analýza biologických odlišností žen a jejich vlivu na pracovní schopnost včetně medicínského hlediska. Na ukázku je možné uvést, že ženské tělo je v průměru o 10 \% menší než mužské, má kratší paže, nižší dosah ruky, o čtvrtinu nižší váhu svalstva, o čtvrtinu nižší dýchací kapacitu a odlišné rozměry některých prstů. ${ }^{19} \mathrm{I}$ když tento pohled vychází především z posuzování role ženy př̌i výrobní činnosti, rozhodně stojí za zamyšlení. Dříve zmíněné hledisko politické konstatuje, že ženy v socialistických zemích by měly mít lepší sociální zabezpečení než ženy v zemích kapitalistických. Další zajímavou studií z období socialismu je výzkumná práce ${ }^{20}$ zabývající se analýzou a definicí invalidity, zejména pak invalidity částečné, $v$ předpisech o sociálním zabezpečení z osmdesátých let mi-

14 Důchodový věk žen a jeho diferenciace. Praha: Československý výzkumný ústav práce a sociálních věcí, 1974.

15 Tamtéž, s. 82

16 Beveridgeova zpráva, anglicky Beveridge Report, oficiálně Sociálni pojištěni a s tím spojené služby, anglicky Social Insurance and Allied Services, byl dokument, který v roce 1942 pro britskou vládu vypracoval ekonom a sociální reformátor William Beveridge. Analýza a návrhy zde představené se staly základem britské verze sociálního státu, v praxi především sociálního pojištění (National Insurance) a systému veřejné zdravotní služby (National Health Service) - viz Beveridgeova zpráva. In: Wikipedie [online]. 2021 [cit. 2021-08-15]. Dostupné na: https://cs.wikipedia.org/wiki/Beveridgeova_zpr\%C3\%A1va Wikipedie.

17 Důchodový věk žen a jeho diferenciace, s. 82

18 Tamtéž, s. 83.

19 Tamtéž, s. 84 a násl.

${ }^{20} \mathrm{KOLBE}, \mathrm{J}$. a kol. Analýza současné definice invalidity, zejména částečné, v československých predpisech o sociálním zabezpečení. II. dỉl. Praha: Československý výzkumný ústav práce a sociálních věcí, 1982. 
nulého století. Z hlediska ekonomické situace bylo konstatováno, že finanční situace poživatelů invalidního důchodu je povětšinou uspokojivá, s tím, že nižší úroveň invalidního důchodu mají občané, kteří pobírají invalidní důchod již od útlého dětství, a také mentálně postižení. ${ }^{21}$ Zdůrazněna byla rovněž potřeba pracovní činnosti poživatelů invalidního důchodu nikoliv pouze $\mathrm{z}$ hlediska přivýdělku, ale především z hlediska jejich pocitu seberealizace, přičemž bylo konstatováno, že značná část částečně invalidních osob musela přijmout práci s nižší kvalifikací, než měla před vznikem invalidity. Podle této studie byly $\mathrm{v}$ osmdesátých letech minulého století vytvořeny dobré podmínky pro zaměstnávání invalidních občanů, avšak bylo zapotřebí zajistit, aby mohli vykonávat více kvalifikovanou práci. ${ }^{22}$

Zajímavou prací je bezesporu i kniha prof. Tomeše mapující jeho kariéru v oblasti práva sociálního zabezpečení. ${ }^{23} \mathrm{Z}$ hlediska smyslu tohoto př́íspěvku je velmi užitečná věta $\mathrm{v}$ rámci úvodní kapitoly, kdy prof. Tomeš zmiňuje, že mu jeho nadřízený důrazně doporučil, aby „,se naučil dějiny sociálního zabezpečení, bez jejichž znalosti nelze pochopit současnost ". ${ }^{24}$ Je to další z důkazů toho, že analýza minulého vývoje v oblasti sociálního pojištění je z hlediska vytváření současné koncepce důchodového systému nesmírně důležitá. Publikace analyzuje proces zrušení diskriminačních výhod horníků, hutníků, chemiků a dalších profesí v sociálním zabezpečení, což se podařilo ještě za federálního Československa, zatímco zavedení penzijního připojištění se realizovalo až v rámci samostatné České republiky v roce 1994. Velkým problémem se ukázalo odmítnutí zaměstnaneckých fondů, zejména pak zaměstnaneckého fondu hornického, který měli financovat majitelé dolů z ceny uhlí, přičemž jeho fungování by bylo na stejném principu jako u britských occupational pensions. ${ }^{25}$ Právě absenci zaměstnaneckých penzijních fondů je možné považovat za jednu z velkých slabin současného českého penzijního systému. Na konci předlistopadového období se objevuje zajímavá analýza týkající se sociálního zabezpečení, a tedy i zabezpečení důchodového. ${ }^{26}$ Kromě analýzy platných právních předpisů z oblasti důchodového zabezpečení, nemocenského zabezpečení, z oblasti společenské pomoci rodinám s dětmi, sociální péče a léčebně-preventivní péče práce konstatuje, že v oblasti důchodového zabezpečení se plně osvědčil princip univerzálnosti a rozvinutý systém dávek.

Stručný rozbor uvedené literatury ukazuje, že vývoj důchodového systému na území dnešní ČR vždy vycházel z konkrétní politické a ekonomické situace, s tím, že se postupně rozšiřoval počet osob, které patřily do okruhu osob pojištěných, a že důchodový systém byl poměrně široce rozvinutý včetně pojišt'ovacího soudnictví. Věcný rozsah pojištění zůstal na přibližně stejné úrovni a jednotlivé právní normy v př́slušných obdobích byly velmi podrobně analyzovány a podrobovány věcnému hodnocení. Postupně

21 ZÁHORSKÁ T. a kol. Průzkum života a potřeb invalidních občanů. Praha: Československý výzkumný ústav práce a sociálních věcí, 1983, s. 214.

22 Tamtéž, s. 217.

23 TOMEŜ, I. Vzpomínky na 60 let v oboru sociální politiky, správy a práva: 1955-2015. Praha: Univerzita Karlova, Nakladatelství Karolinum, 2019.

24 Tamtéž, s. 12.

25 Tamtéž, s. 102.

26 PŘIB, J. - RÝZNAR, L. - SAMEK, V. Zákon o sociálním zabezpečení: výklad a aplikace v praxi. Pardubice: Československá vědecko-technická společnost - Dům techniky ČSVTS Pardubice, 1988. 
byly rozvíjeny i příslušné zásady, na kterých bylo pojištění založeno. Důležitou roli hrála také ochota věnovat se problematice důchodového pojištění a hledání zdrojů pro jeho financování. Je možné vyslovit hypotézu, že historický vývoj důchodového systému byl odrazem tehdejší ekonomické a politické situace se snahou o odborné zdůvodnění daného vývoje.

\section{STRUČNÁ PRÁVNÍ ANALÝZA A ZHODNOCENÍ V JEDNOTLIVÝCH OBDOBÍCH}

\subsection{OBDOBÍ PŘED VZNIKEM SAMOSTATNÉ ČSR}

Zákon č. 1/1907 ř. z. ${ }^{27}$ již zcela komplexně postihuje problematiku důchodového pojišsění v rámci Rakouska-Uherska. Osobní rozsah pojištění je dán pozitivně vyjmenovanými osobami, na které se pojištění vztahuje, a dále pak negativně vyjmenovanými osobami, na které se důchodové pojištění nevztahuje. Osobní rozsah pojištění je limitován na vybrané kategorie občanů. Nejlépe na tom byli veřejní zaměstnanci, kteří měli definitivní státní pojištění, které bylo součástí jejich pracovního poměru. ${ }^{28}$ Relativně dobře ošetřené podmínky měli rovněž učitelé či horníci. Věcný rozsah pojiššení je poměrně široký, nebot' zahrnuje nejen starobní důchod, ale i důchod vdovský, invalidní a také určitou formu důchodu sirotčího, tj. všechny základní formy důchodů, které jsou známy také ze současné legislativy. $Z$ hlediska př́slušných základních parametrů, tak jak je známe i ze současnosti, jsou identifikovány především doba odchodu do důchodu a minimální doba pojištění. Starobní důchod je prvně právně zakotven na území současné ČR, s tím, že se připouští možnost nároku na odpočinek zaměstnance bez toho, aby byl stižen nemocí nebo úrazem. Do té doby byla řešena především problematika úrazového pojištění jakožto ztráty výdělku v důsledku vzniklého úrazu nebo ztráty výdělku $\mathrm{v}$ důsledku nemoci. Přijetím zákona o důchodovém pojištění, byt' pro omezené skupiny osob a za relativně př́sných podmínek, se i území současné ČR zařadilo mezi sociálně nejvyspělejší oblasti na světě. Zř́izen byl Ústav pensijní se sídlem ve Vídni, který měl na starosti organizaci penzijního pojištění.

Za klíčový je možné považovat fakt, že si společnost poprvé ve své historii začíná uvědomovat nutnost komplexnějšího důchodového zabezpečení alespoň určitých skupin obyvatelstva, včetně relativně vysokého zabezpečení rodinných př́islušníků pro prrípad ztráty živitele. Poprvé se pracuje s pojmy jako soustavná př́prava na budoucí povolání nebo naopak neschopnost se prripravovat na budoucí povolání. Za relativní výhodu tohoto systému důchodového pojištění je možné považovat také vysoce sofistikované organizační zabezpečení celého systému, které zabezpečoval Pensijní ústav se sídlem ve Vídni. Mezi základní nevýhody systému důchodového pojištění v daném období patř́i bezesporu jeho orientace pouze na určité skupiny obyvatel, přičemž i každá

27 Zákon č. 1/1907 ř. z., o penzijním pojištění zřízenců ve službách soukromých a některých zřízenců ve službách veřejných.

28 MALÝ, K a kol. Dějiny českého a československého práva do roku 1945. 4. přepr. vyd. Praha: Leges, 2010, s. 288. 
z př́islušných skupin má svoji samostatnou zákonnou úpravu. Vysoký je také věk odchodu do starobního důchodu vzhledem k průměrnému věku dožití v dané době.

\subsection{OBDOBÍ OD ROKU 1918 DO ROKU 1945}

Penzijní pojištění v období první Československé republiky vycházelo ze zákonných úprav bývalého Rakouska-Uherska, kdy byly pojištěny vybrané skupiny obyvatel, zejména zaměstnanci ve státních službách a dále pak zaměstnanci, kteří vykonávali práci duševní, zejména v kancelářích, nebo dozírali na práci druhých osob. V roce 1924 přichází zákon č. 221/1924 Sb., ${ }^{29}$ úprava, která řešila pojištění pro př́pad stáŕí a invalidity a která byla na svoji dobu relativně velmi pokroková; v podstatě poprvé byly pojištěny i širší vrstvy obyvatel včetně dělnictva, i když z dnešního úhlu jen na velmi nízké úrovni zabezpečení. Pojištění se nevztahovalo však na osoby starší šedesáti let, které pak byly následně zajištěny jakousi roční starobní podporou, která navíc byla v př́padě více osob v rámci jedné domácnosti krácena. Za určitou originalitu je možné považovat sjednocení dávek sociálního pojištění a propojení v rámci jednoho systému jak dlouhodobých, tak i krátkodobých sociálních dávek, a také pokrytí širokého spektra zaměstnanců v rámci tohoto zákona. ${ }^{30}$ Podmínky tohoto důchodového zajištění se postupně se zvyšující se životní úrovní během období první Československé republiky zlepšovaly. Věk odchodu do důchodu byl stanoven na úroveň 65 let, což byl na tehdejší dobu věk relativně vysoký. Samostatně bylo řešeno pojištění horníků a osob samostatně hospodařících. Celkově je možné konstatovat, že období předválečné ČSR bylo charakteristické relativně velmi vyspělým systémem sociálního pojištění včetně pojištění důchodového. Kromě kvalitních hmotněprávních norem je třeba zmínit i velmi kvalitní procesní zákonodárství v oblasti sociálního zabezpečení včetně důchodového pojištění. Unikátní bylo např. zřízení speciálního pojišt’ovacího soudu, o kterém bude zmínka ještě v rámci organizačního zabezpečení důchodového pojištění v daném období. V období Protektorátu Čechy a Morava dochází pouze k dílčím úpravám některých zákonných úprav z období první Československé republiky s cílem valorizace důchodů a také zkrácením čekací doby na důchod. Valorizační zvyšování důchodů se dělo především na základě příslušných vládních nařízení. Silné inflační tlaky byly kompenzovány vybraným skupinám zaměstnanců, které byly považovány za klíčové pro válečné hospodářství, např. horníkům. Vzhledem k nutnosti jednat relativně rychle se realizovala většina opatření na základě příslušných vládních nařízení. Cílem bylo mimo jiné eliminovat případné projevy sociální nespokojenosti, nebot' okupační správa potřebovala zabezpečit klid pro zajištění stále náročnější válečné výroby.

Osobní rozsah pojištění v daném období se týkal především vybraných skupin obyvatel, s tím, že postupně docházelo k vytváření dalších skupin, čímž docházelo k tomu, že postupně větší počet obyvatel byl zabezpečen důchodovým pojištěním. Věcný rozsah pojištění se týkal především starobních důchodů, důchodů vdovských a vdoveckých, dále pak sirotčích, invalidních, ale také výbavného a státní starobní podpory. Pojiš-

29 Zákon č. 221/1924 Sb., o pojištění zaměstnanců pro případ nemoci, invalidity a stárí, ze dne 9. ř́ijna 1924.

30 TOMES̆, I. 90 let sociálního pojištěni v České republice: statě z let 2014-2016. Praha: BMSS-Start, 2016, s. 12. 
tovací povinnosti spočívaly především v placení pojistného, na kterém se podíleli jak zaměstnanec, tak i zaměstnavatel. K pojištění bylo třeba se přihlásit v souladu s př́slušným zákonem. Za výhodu systému důchodového pojištění v daném období je možné považovat především skutečnost, že již značná část obyvatelstva začíná být důchodově pojištěna. I když důchodové pojištění je stále ještě relativně roztříštěné na jednotlivé skupiny obyvatelstva, nelze přehlédnout relativně značný pokrok v této problematice, kdy systém důchodového pojištění v př̌edválečné ČSR byl jedním z nejvyspělejších na světě. Týkalo se to nejen hmotněprávních otázek, ale také i práva procesního. Věková hranice 65 let byla na tehdejší dobu stále vysoká, což je do určité míry eliminováno zvyšujícím se věkem dožití. Za pozitivum je možné také považovat valorizace důchodů $\mathrm{v}$ důsledku vysoké inflace, která se projevila především v období protektorátu. Mezi základní nevýhody systému důchodového pojištění v daném období patří nejednotnost úpravy, kdy každá z př́slušných skupin obyvatel má svoji samostatnou zákonnou úpravu, prričemž velké rozdíly jsou také ve štědrosti důchodových plateb podle jednotlivých zákonných úprav. Další nevýhodou mohou být relativně náročné podmínky, které je třeba pro odchod do starobního důchodu splnit, zejména pokud se týká odpracovaných nebo odsloužených let.

\subsection{OBDOBÍ OD ROKU 1945 DO ROKU 1992}

Protože toto období je relativně široké, je vhodné se zaměřit i na jednotlivé dílčí periody, které se zde vyskytly. Počátek dané periody je možné rozdělit na dvě zásadní období. První se týká realizace systému národního pojištění, který byl v podstatě připravován již během druhé světové války exilovou vládou v Londýně, přičemž byl inspirován již dříve zmíněným dílem Williama Beveridge z roku 1942 s názvem Social Insurance and Allied Services, jehož zestručnění bylo také přeloženo do češtiny. ${ }^{31}$ Podstatou tohoto př́stupu bylo vybudování sebevědomého systému sociálního pojištění, které by bylo založeno na principu univerzálního zabezpečení občanů dané země a nahrazení dosavadních stavovských pojišt'ovacích systémů. Idea vybudování sociálního státu s cílem zajistit „sociální bezpečnost“32 se realizovala prakticky ve všech vyspělých, především evropských zemích po druhé světové válce, s tím, že sociální bezpečnost se měla stát jakýmsi nárokovým statkem, a nikoliv pouze jakousi almužnou či charitou státní moci vůči svým občanům. Sociální bezpečnost byla řešena $v$ rámci systému sociálních a hospodářských práv, ${ }^{33}$ která byla mimo jiné řešena i v rámci Ústavy 9. května 1948. Klíčové pro sociální pojištění bylo především sjednocení dřivějších oddělených a samostatných oborů sociálního pojištění, tak jak byly známy především z předválečného období. Důležitým rysem tohoto období bylo také zajištění poválečné kontinuity celého důchodového systému včetně uznání nároků získaných v cizině a včetně valorizace důchodů ze sociálního pojištění. Uznání zahraničních nároků zahrnovalo práci v zahraničí v období nesvobody, dále pak případy reemigrace, otázku lidí pracujících v postoupeném pohraničí či také otázku obyvatel Zakarpatské Ukrajiny, která byla po válce

31 KUKLÍK, J. a kol. Vývoj československého práva 1945-1989. Praha: Linde, 2009, s. 237.

32 Tamtéž.

33 Tamtéž. 
postoupena Sovětskému svazu. Nároky se vztahovaly na př́ípady invalidity, stáří a úrazu u cizozemského nositele pojištění3 ${ }^{34}$ a měli na ně nárok i pozůstalí po osobách, kteří měli na výplatu nárok. ${ }^{35}$ Za období nesvobody bylo považováno období od 30. září 1938 do 4. května 1945. ${ }^{36}$ Druhé období se týká první poloviny padesátých let, kdy bohužel dochází k promítání silného vlivu sovětského práva sociálního zabezpečení, což je proces, který vyvrcholil především přijetím zákona o sociálním zabezpečení z roku 1956. Tento vliv se promítal především v oddělení nemocenského a důchodového pojištění, dále pak v rozdělení zaměstnanců do tří základních kategorií podle významnosti pro nový komunistický režim, kdy byly preferovány především dělnické profese z oblasti hornictví a těžkého průmyslu, právě po vzoru sovětského systému, přičemž se jednalo o fyzicky velmi náročné profese, s tím, že naopak význam duševní práce byl potlačován. Právě toto členění na tři kategorie zaměstnanců bylo podle odborné literatury ${ }^{37}$ nejvíce kritizovanou oblastí systému sociálního pojištění v období komunistické vlády. Další zásadní změnou vlivem promítání sovětského práva byla změna principu pojištění na princip zabezpečení, které platí stát ze státního rozpočtu, a kdy není zapotřebí být tzv. pojištěn. Ke splnění nároku na výplatu důchodu pak „stačilo“ splnit zákonem dané podmínky, což bylo např̀. $v$ případě důchodového zabezpečení dosažení důchodového věku a minimálního počtu odpracovaných let či případně splnění dalších podmínek. Důchodový systém byl relativně velmi štědrý, především co se týká starobních důchodů žen, které mohly odcházet do starobního důchodu ve věku 53 až 57 let podle počtu vychovaných dětí. Také u mužů se snížil věk odchodu do starobního důchodu na 60 let. Tyto štědré podmínky společně s prodlužujícím se věkem průměrného dožití znamenaly zvyšující se počet důchodců a také vyšší zátěž pro státní rozpočet. $K$ tomu je nutné přidat i systém osobních a sociálních důchodů.

V rámci sedmdesátých let dochází k definitivnímu sjednocení důchodů pod jednu právní úpravu, pod kterou bylo subsumováno důchodové zabezpečení družstevních rolníků. Speciální formou důchodu byl důchod za výsluhu let u vybraných profesí. Tento systém důchodového pojištění, respektive zabezpečení, pak přetrval až do roku 1990 a s určitými úpravami pak i do konce federace v roce 1992. Dochází ke zpětnému přechodu od důchodového zabezpečení k důchodovému pojištění, přičemž v tomto období za určitý mezistupeň je možné považovat používání výrazu zabezpečení, s tím, že na důchodové zabezpečení je třeba platit pojištění.

Z hlediska osobního rozsahu jsou v daném období pojištěni všichni zaměstnanci, tj. jak dělníci, tak úředníci, horníci aj., samostatně hospodařící rolníci a členové jednotných zemědělských družstev. Pro výplatu příslušných dávek bylo třeba splnit př́islušné podmínky, např. u starobního důchodu věk a dobu zaměstnání. Mimochodem v analyzovaném období dochází ke snížení dlouhotrvající hranice pro odchod do důchodu 65 let na hodnotu 60 let, přičemž se rozlišuje hranice pro odchod do důchodu mužů a žen. Vycházelo se z faktu, že ženy jsou kvůli souběhu zaměstnání a péče o rodinu více zatíženy a mají nárok na dřívější odchod do důchodu. Souviselo to jednak s velmi sil-

$34 \S 1$ zákona č. 17/1947 Sb., o uznání nároků získaných u cizozemských nositelů sociálního pojištění

35 § 1, odst. 4 zákona č. 17/1947 Sb., o uznání nároků získaných u cizozemských nositelů sociálního pojištění.

36 § 1, odst. 8 zákona č. 17/1947 Sb., o uznání nároků získaných u cizozemských nositelů sociálního pojištění.

37 KUKLÍK, c. d., s. 244. 
nou prorodinnou politikou komunistické vlády a dále pak se skutečností, že komunisté potřebovali výrazněji zapojit ženy do pracovního procesu, ale zároveň předpokládali $i$ jejich péči o rodinu. $Z$ hlediska věcného existovaly $\mathrm{v}$ tomto období velmi podobné typy důchodů, jako tomu bylo v predcházejícím období, kdy se jednalo především o starobní důchod, vdovský důchod, vdovecký důchod, sirotčí důchod, důchod manželky, důchod za výsluhu let i sociální a osobní důchod. Výši důchodu ovlivňovala zásadní pojišt’ovací povinnost a tou byla doba, po kterou byla osoba zaměstnána, přičemž existovala minimální doba v rozsahu dvaceti let. Do této lhůty se započítávala nejen doba zaměstnání, ale i doba např. vojenské základní služby, mateřské dovolené, ale i odbojová činnost během války. Specifickým typem důchodu z tohoto období byl osobní důchod, který byl přiznáván nikoliv podle objektivních pravidel, ale subjektivně na základě předchozích zásluh o rozvoj národního hospodářství či vědy nebo kultury. Oproti minulému období dochází i k zásadní změně v oblasti organizačního zabezpečení důchodového pojištění, kdy byla překonána určitá roztř́śštěnost systému tohoto pojištění reprezentovaná př́slušnými subjekty tak, jak je známe např. z období první republiky, ale objevuje se jediný nositel pojištění, kterým byla již dřive zmíněná Ústřední národní pojištovna se sídlem v Praze, která byla organizačně rozčleněna na jednotlivé okresní národní pojišt’ovny. Pojistné měli platit dle zákona zaměstnavatelé, ${ }^{38}$ ale velmi záhy došlo $\mathrm{k}$ návratu $\mathrm{k}$ predchozí praxi, kdy část pojištění platil zaměstnanec a část zaměstnavatel. ${ }^{39}$ Později v souladu s politikou sociálního zabezpečení, a nikoliv sociálního pojištění, byly pojistné platby zaměstnavatelů zrušeny a nahrazeny financováním důchodů prostřednictvím státního rozpočtu, přičemž v souvislosti s reformou daňového systému dochází ke skryté platbě pojiššení včetně důchodového v rámci nově zavedené daně ze mzdy. ${ }^{40}$ V souvislosti se zavedením systému důchodového zabezpečení prostřednictvím státního rozpočtu vzniká Státní úřad důchodového zabezpečení se sídlem v Praze a s oblastní pobočkou v Bratislavě. Př́ijmy a výdaje této instituce byly přímo napojeny na státní rozpočet. $\mathrm{V}$ rámci daného období existuje rovněž krátký úsek v období po listopadové revoluci v roce 1989 do konce československé federace v roce 1992. V tomto krátkém období došlo především ke zrušení preferencí a diskriminace $\mathrm{v}$ rámci důchodového systému. Jednalo se zejména o zrušení již dříve zmiňovaných osobních důchodů a dále pak ošetření důchodů osob samostatně výdělečně činných.

Hlavní výhodou důchodového systému v daném období bylo bezesporu důchodové zabezpečení téměř všech obyvatel země a také jednotná právní úprava, byt's rozlišením jednotlivých tříd zaměstnanců, přičemž finanční zabezpečení nebylo vázáno na platbu pojištění. Systém důchodového pojištění skýtal oproti předcházejícím obdobím relativně důstojný život invalidních i starobních důchodců. A především, byl výrazným způsobem snížen věk odchodu do starobního důchodu, prričemž zejména u žen byl ve vztahu k průměrnému věku dožití jednoznačně nejvýhodnější na území ČR v celé historii. Relativně štědrý a dobře propracovaný byl i systém náhradních dob pojištění. Vysoké byly i vdovské a vdovecké důchody.

38 § 120 Zákon č. 99/1948, o národním pojištění.

39 § 1 Nařízení vlády č. 220/1948 Sb., jímž se stanoví části, které z pojistného v národním pojištění hradí zaměstnavatel a zaměstnanec.

40 Zákon č. 76/1952 Sb., o dani ze mzdy. 
Nevýhodou celého systému důchodového zabezpečení v daném období byla jeho relativně velká finanční náročnost a také poměrně vysoký politický vliv, kdy byly v rámci důchodového systému preferovány profese, které komunistický režim považoval za klíčové.

\subsection{OBDOBÍ OD ROKU 1993 DO ROKU 2021}

V rámci samostatné České republiky dochází k opětovnému plnému návratu k systému sociálního pojištění včetně pojištění důchodového a nahrazení předchozího systému sociálního zabezpečení. Dochází také k oddělení pojistných plateb od placení daní zaměstnanci a $\mathrm{k}$ návratu rozdělení platby pojistného na důchodové pojištění zaměstnanci a zaměstnavateli. Zůstává zachován průběžný systém důchodového pojištění, kdy důchody jsou vypláceny ze státního rozpočtu, do kterého jdou i platby důchodového pojištění $\mathrm{v}$ rámci samostatné kapitoly. Dochází k posílení univerzálnosti důchodového systému, nebot' jsou zrušeny kategorie pracovníků (zaměstnanců) a rozhodující je vyměřovací základ a doba pojištění včetně tzv. náhradních dob pojiššění. Jsou stanoveny jasné a pro všechny stejné podmínky. Zavedení jednotného a univerzálního systému důchodového pojištění však není jediný problém, se kterým se musí stát v tomto období v oblasti důchodového pojištění vypořádat. Po roce 1989 dochází $\mathrm{k}$ výraznému poklesu porodnosti, která byla $\mathrm{v}$ minulosti podporována relativně silnou prorodinnou politikou. Kromě toho díky zlepšující se kvalitě zdravotní péče a také zlepšujícímu se životnímu prostředí dochází $\mathrm{k}$ prodlužování průměrného věku dožití a s tím souvisejícímu delšímu vyplácení starobních důchodů. Tím se výrazně zvyšuje zátěž státního rozpočtu při průběžném financování důchodového systému. Proto je pro toto poslední analyzované období charakteristická snaha o realizaci důchodové reformy. Z hlediska teorie důchodového pojištění je možné uvažovat o tzv. parametrické reformě či o reformě systematické. Obojí v analyzovaném období proběhlo. Parametrická reforma se jeví jako „mírnějšsi“ a představuje pouze změnu určitých parametrů, prričemž mezi klíčové patř́i zejména minimální doba pojištění včetně náhradních dob pojištění a pochopitelně i věk odchodu do důchodu. Reforma systematická pak znamená zavedení dalších piliřru důchodového systému, tj. druhého povinně fondového a třetího na bázi dobrovolného penzijního připojištění. Dané období je charakteristické prováděním jak parametrické, tak systémové reformy. Parametrická reforma byla představována postupným zvyšováním doby odchodu do důchodu, a to až na úroveň 65 let, přičemž postupně má docházet i k vyrovnávání doby odchodu do důchodu mužů a žen bez ohledu na počet vychovaných dětí. Zejména vyrovnávání věku odchodu do důchodu mezi muži a ženami vyvolávalo značné kontroverze, nebot' značná část veřejnosti považovala a stále považuje ženy za více vytížené kombinací zaměstnání a péče o rodinu. $Z$ hlediska čistě právního se však $\mathrm{v}$ př́ípadě nestejného důchodového věku může jednat o diskriminaci, která byla řešena např. v rámci Evropského soudu pro lidská práva. ${ }^{41}$ Kromě zvyšování věku odchodu do důchodu dochází postupně také k prodlužování povinné doby pojištění, z původních 25 let na 35 let doby pojišsění, či náhradních dob pojištění. V současnosti se

41 Andrle proti České republice. Rozsudek senátu 5. sekce. Č́slo stížnosti: 6268/08. 
ukazuje, že i změna tohoto parametru může činit určité potíže zejména pro matky, které byly dlouho doma se svými dětmi, nebo i pro dlouhodobě nezaměstnané. Za určitou systémovou reformu je možné považovat i zavedení třetího dobrovolného pilíře důchodového pojištění po vzoru vyspělých západních zemí v roce 1994, kdy byl přijat zákon o důchodovém připojištění se státním př́spěvkem, který umožnil občanům nad rámec povinného důchodového pojištění se na důchod připojistit, a tím si zajistit v důchodovém věku vyšší životní standard. Penzijní připojišsění bylo postupně upravováno a od roku 2012 funguje jako doplňkové penzijní spoření, přičemž stávající penzijní připojištění se státním př́ispěvkem bylo zakonzervováno do transformovaného fondu. V České republice, podobně jako tomu bylo i v dalších zemích střední a východní Evropy, byl zaveden druhý důchodový piliřr na bázi povinného fondového. Bohužel k zavedení tohoto systému je zapotřebí velký objem počátečního kapitálu, který v těchto zemích nebyl $\mathrm{k}$ dispozici. Je totiž třeba pokrýt počáteční výpadek př́ijmů z pojistného, které jde místo do prvního průběžného piliře do pilíře druhého, fondového. Další problém spočívá v nedůvěře občanů zemí střední a východní Evropy, včetně České republiky, k soukromým fondům. Tato nedůvěra se vytvořila během privatizace, kdy mnoho soukromých fondů zkrachovalo či byly vytunelovány. Není proto divu, že prakticky v žádné zemi v této oblasti se systémová reforma spočívající v zavedení druhého pilirire neujala. $V$ některých zemích druhý piliřr skomírá, v některých včetně České republiky byl dokonce zrušen. ${ }^{42}$ Zavedení systematické důchodové reformy a její následné zrušení není z hlediska celkové stability důchodového pojištění dobrá věc, a proto by bylo z právního hlediska dobré, pokud by pro případ implementace nějaké budoucí důchodové reformy či jejího př́padného zrušení byl zapotřebí stejný počet hlasů $v$ Poslanecké sněmovně Parlamentu České republiky a v Senátu Parlamentu České republiky, jako je tomu v případě přijímání ústavních zákonů.

Osobní rozsah pojištění $\mathrm{v}$ tomto období je dán zákonnou úpravou a je pro všechny osoby výdělečně činné a také pro některé osoby, které jsou v situaci, která jim v této výdělečné činnosti brání. Věcný rozsah pojištění je charakterizován různými druhy důchodů, které se dělí na důchody př́imé a odvozené, prričemž u přímých se procentní výměra stanoví přímo od výše prríjmů pojištěnce, zatímco v př́ípadě odvozených se počitá z výše př́ijmu nebo důchodu jiné osoby. ${ }^{43}$ Mezi první skupinu patří především starobní a invalidní důchod, do druhé skupiny pak důchody pozůstalostní. Základní výhodou současného systému důchodového pojištění je jeho jednotná úprava, která platí pro všechny občany, kteří jsou důchodově pojištěni. Postupně dochází i ke srovnání podmínek pro získání starobního důchodu u mužủ i u žen. Další výhodou je dobré organizační zabezpečení systému důchodového pojištění na bázi ČSSZ, kdy zároveň existuje velmi dobrá vymahatelnost práva a možnost opravných prostředků.

42 Bližší podrobnosti ohledně důchodových reforem v zemích střední a východní Evropy včetně České republiky jsou uvedeny např. v HRDÝ, M. Analýza di̊chodových systémů a jejich možná aplikace v ČR. Praha: Univerzita Karlova, Právnická fakulta. Rigorózní práce. 2016.

43 CHVÁTALOVÁ, I. a kol. Právo sociálniho zabezpečeni v České republice a v Evropské unii. Plzeň: Vydavatelství a nakladatelství Aleš Čeněk, 2012, s. 134. 


\section{DOPORUČENÍ DE LEGE FERENDA VYPLÝVAJÍCÍ Z PŘEDCHOZÍ ANALÝZY}

Z historického vývoje důchodových systémů na území dnešní České republiky je třeba si vzít poučení, které je možné využít pro stanovení budoucí strategie vývoje důchodového systému na území České republiky do budoucnosti. Kromě identifikace vhodného důchodového systému je třeba správně nastavit parametry, které právě zajistí dobře fungující systém. Jedná se především o dobu odchodu do starobního důchodu, nebo o minimální dobu pojištění či o stanovení př́islušných redukčních hranic a jejich výše, a tím identifikaci míry zásluhovosti. Je třeba také identifikovat zdroje, z jakých bude důchodový systém financován a s tím související vymezení, jaká výše průměrného starobního důchodu ve vztahu např. k průměrné mzdě je pro společnost přijatelná. Ohledně doporučení pro budoucí systém důchodového pojištění je třeba nejprve zvážit, na jakých piliríích by měl tento systém stát. Vzhledem k negativním zkušenostem ohledně druhého povinného fondového piliřre nejen v České republice, ale i v dalších zemích střední a východní Evropy, není vhodné se pokoušet tento pilír znovu obnovovat a je třeba se soustředit na kombinaci prvního průběžného piliíre a třetího dobrovolně fondového, $\mathrm{s}$ tím, že $\mathrm{v}$ rámci prvního průběžného pilirire bude vhodné vymezit ještě tzv. nultý piliŕ představující základní důchod, na který bude mít nárok každý poživatel starobního, popřípadě i invalidního důchodu. Tento základní důchod by byl hrazen z př́islušných daňových výnosů ze státního rozpočtu. První piliír by pak odrážel především zásluhovost a velikost odvedeného pojistného za př́slušné období. Důležitá bude také očekávaná životní úroveň důchodců vyjádřená zejména výší průměrného důchodu vzhledem $\mathrm{k}$ výši průměrné mzdy. Dosavadní výplatní poměr průměrného starobního důchodu se pohybuje na úrovni $50 \%$ čisté mzdy ${ }^{44}$ a bude vhodné ho zvýšit tak, aby průměrný důchod činil alespoň $60 \%$ průměrné čisté mzdy v národním hospodářství. Pochopitelně ruku v ruce $\mathrm{s}$ těmito úvahami je třeba také identifikovat finanční zdroje, ze kterých bude tento systém financován. Ke zvýšení daňových výnosů státu by mohlo dojít především v oblasti nejen spotřebních daní, ale také např. daňovou progresí u právnických osob (zavedení druhé sazby daně) nebo zavedením sektorových daní, např. u bank, velkých energetických firem, nadnárodních koncernů apod., které odvádějí z ČR vysoké dividendy do zahraničí, aniž by náš stát měl z těchto výnosů dostatečný podíl. U prvního důchodového piliíre by bylo vhodné posílit více zásluhovost mimo jiné i tím, že by došlo ke zvýšení hodnoty redukční hranice z dosavadních $44 \%$ průměrné mzdy např. na hodnotu $50 \%$ průměrné mzdy, což by vedlo opět ke zvýšení hodnoty důchodů a $\mathrm{k}$ větší zátěži v rámci prvního důchodového piliriře. Tato větši zátěž by mohla být řešena zvýšením sazby důchodového pojištění u zaměstnanců, nikoliv zaměstnavatelů. $Z$ politického hlediska by mohly nastat problémy s prosazením tohoto relativně nepopulárního opatření, avšak je třeba si uvědomit, že stále žijeme ve společnosti, kde platí mimo jiné i solidarita mladých se starými a tato solidarita musí být také v praxi realizována, tak jako to vyplývá i z historického vývoje. Pracovně aktivní občané se musí postarat o občany pracovně

44 Starobní důchod loni klesl na 50 \% průměrné čisté mzdy. In: FINTAG.cz [online]. 21. 11. 2019 [cit. 2021-08-15]. Dostupné na: https://www.fintag.cz/2019/11/21/starobni-duchod-loni-klesl-na-50 -prumerne-ciste-mzdy/. 
neaktivní, a pokud jich bude málo, bude na každého připadat větší zátěž. Pro mnohé je to těžko pochopitelné, ale je to tak. Určitou alternativou ke zvyšování důchodového pojištění placeného zaměstnanci či OSVČ by mohla být silná prorodinná politika státu, tj. motivování lidí $\mathrm{k}$ tomu, aby měli děti. Co se týká třetího dobrovolného fondového pilíre, bylo by vhodné zvýšit motivaci lidí ke spoření v tomto pilírí, a to zejména $\mathrm{z}$ hlediska částek, které lidé spoří. Zvýšení státního př́spěvku je však značně diskutabilní, protože by znamenalo další zátěž výdajové stránky státního rozpočtu. Cesta by však mohla vést přes možnost vyšší podpory zaměstnavatelů, kteří bohužel hrají v rámci celého důchodového systému, nejen $v$ rámci třetího pilíře, poměrně malou roli, oproti především vyspělým západním zemím. V rámci České republiky však byl určitý pokus zaměstnavatele více zapojit, a to sice prostřednictvím připravovaného zákona, ${ }^{45}$ který však nenabyl nikdy účinnosti. Tento zákon předpokládal existenci důchodových fondů zaměstnavatelů, do kterých by mohl zaměstnanec vstoupit na dobrovolné bázi, a při splnění stanovených podmínek by mu vznikl nárok na výplatu př́slušné dávky. $Z$ hlediska fungování celého systému je možné považovat za vhodné zachování jednotného systému důchodového pojištění a odmítnout snahy o zavedení možnosti dř́vějšího odchodu do důchodu u vybraných profesí. Trvalo v rámci historického vývoje velmi dlouho, než se podařilo tento jednotný systém vybudovat, a byla by škoda ho opustit. Obtížnost výkonu některých profesí v pozdějším věku by se měla řešit motivováním zaměstnavatelů, např. daňovými úlevami, zaměstnávat starší lidi na pozicích, které mimo jiné odpovídají jejich věku. S tím souvisí i otázka základního parametru důchodového systému, věku odchodu do důchodu. Především u některých profesí je věk 65 let již poměrně vysoký a přes demografické problémy, které se ve většině zemí v současné době vyskytují, je třeba postupovat velmi opatrně. Pokud bychom se měli vrátit k situaci před zastropováním věku odchodu do důchodu, bylo by případně možné se odrazit od ročníku narození 1977, který měl jít do důchodu v 67 letech, a nastavit zde jako u posledního ročníku narození věk odchodu do důchodu na úroveň 65 let a poté pozvolna př́ípadně zvyšovat za každý rok narození o 2 měsíce do max. věku sedmdesáti let, což bude patrně limitní hranice schopnosti člověka pracovat bez ohledu na případné prodlužování průměrného věku dožití. S věkem odchodu do důchodu prímo souvisí také minimální doba pojištění, která činí v současné době 35 let. Tato doba je často kritizována jako velmi dlouhá a jedna z nejdelších v Evropě, avšak patrně by nebylo vhodné ji zkracovat, nebot' by lidé měli být motivováni $\mathrm{k}$ práci. Na druhé straně by $\mathrm{v}$ této souvislosti mohlo dojít $\mathrm{k}$ vylepšení podmínek náhradních dob pojištění, které byly během doby samostatné České republiky zpř́sněny a mohly by být více uvolněny, tak jak tomu bylo i v historii. Týká se to např. uznávání doby vysokoškolského studia i po roce 2010 či prodloužení doby pojištění v př́ípadě nezaměstnanosti, která činí v současné době maximálně tři roky, z toho rok do dosažení 55 let. Tato doba by mohla být prodloužena např. na 5 let. Na trhu práce se totiž dají v souvislosti s postupující automatizací a robotizací očekávat relativně velké změny, které mohou vyvolávat vyšší dočasná období nezaměstnanosti. Tím by došlo k určité kompenzaci právě vysoké výše uvedené minimální doby pojištění. Z hlediska organizačního zabezpečení systému důchodového pojištění v České republice je

45 Zákon č. 340/2006 Sb., o činnosti institucí zaměstnaneckého penzijního pojištění, ze dne 24. května 2006. 
možné konstatovat, že tento systém zabezpečovaný především prostřednictvím ČSSZ je plně funkční a vyhovující včetně možnosti využití opravných prostředků a není třeba ho nijak zásadně měnit. Klíčovým poznatkem z hlediska historického vývoje pro další vývoj důchodového systému v ČR je především skutečnost, že značná část přijatých opatření v oblasti důchodového pojištění byla v minulosti výrazně podložena odbornými studiemi, které se snažili co nejobjektivněji posoudit vhodnost zavádění př́islušných opatření. To je záležitost, která $\mathrm{v}$ dnešní době do jisté míry chybí, a převažuje hledisko politické, s tím, že je velmi obtížné najít politický konsenzus $\mathrm{k}$ dané problematice. Dalším problémem je skutečnost, že během historického vývoje docházelo bez ohledu na politický režim k postupnému zlepšování podmínek důchodového pojištění, zatímco $\mathrm{v}$ současnosti je nutné se vypořádat s problémem vysokého počtu lidí důchodového věku na jedné straně a nižšího počtu obyvatel v produktivním věku na straně druhé, což v konečném důsledku vede ke zhoršení některých parametrů důchodového systému, zejména pak k tlaku na zvyšování věku odchodu do starobního důchodu a také k prodlužování minimální doby důchodového pojištění.

\section{ZÁVĚR}

Cílem tohoto článku bylo prezentovat klíčové aspekty vývoje důchodového systému na území ČR od počátku 20. století po současnost a na základě této identifikace a rozboru vyvodit př́slušná doporučení pro vývoj důchodového pojištění v ČR do budoucnosti. Byla vyslovena hypotéza, že historický vývoj důchodového systému byl odrazem tehdejší ekonomické a politické situace se snahou o odborné zdůvodnění daného vývoje. Tento cíl byl splněn a stanovená hypotéza byla v podstatě potvrzena, nebot' př́slušná legislativa vždy vycházela z ekonomických možností a také byla poplatná politické situaci v daném období. V úvodu článku byla stručně rozebrána vybraná literatura vztahující se $\mathrm{k}$ př́íslušným obdobím daného vývoje důchodového pojišš̌ní na území dnešní ČR. Tento rozbor prokázal, že důchodové pojištění postupně rozšiřovalo okruh pojištěných osob, a to $\mathrm{v}$ závislosti na právní i ekonomické vyspělosti dané společnosti. Zdůraznit je třeba také rozsáhlou odbornou debatu týkající se vybraných problémů důchodového pojištění, napřr. otázky dřívějšího odchodu žen do starobního důchodu. Vlastní identifikace a rozbor byl proveden pro čtyři základní období (před vznikem samostatné ČSR, období let 1918-1945, období let 1945-1992 a období samostatné ČR), a to zejména s důrazem na osobní, věcný a organizační rozsah důchodového pojištění. Zatímco věcný rozsah zůstával zhruba stejný a v zásadě byly vypláceny přibližně stejné druhy důchodů, osobní rozsah se postupně rozšiřoval, s tím, že nakonec vedl $\mathrm{k}$ jednotnosti $\mathrm{v}$ oblasti důchodového pojištění. Organizace důchodového pojištění byla na území dnešní ČR vždy na vysoké úrovni a patřila vždy ke světové špičce. Rostoucí životní úroveň umožňovala zlepšování podmínek pro přiznání a výplatu starobního i invalidního důchodu, což vedlo ke zvyšování životní úrovně jak starobních, tak invalidních důchodců. V období totality, at již nacistické, či komunistické, byla důchodová legislativa uzpůsobena požadavkům režimu, s tím, že byly např. důchodově zvýhodňovány vybrané profese a lidé, kteří měli př́slušné zásluhy na rozvoji režimu. 
Poučením pro současnost je i skutečnost, že je třeba se více zabývat odbornými aspekty a hledat širší politický konsensus. Je vhodné pokud možno ponechat jednotný systém důchodového pojištění se státním důchodem rozděleným na nultý piliř financovaný ze státního rozpočtu a první piliir na bázi zásluhové a dále možnost doplňkového penzijního pojištění s větší rolí zaměstnavatelů. $Z$ historického vývoje důchodových systémů na území dnešní České republiky je třeba si vzít poučení, kdy kromě identifikace vhodného důchodového systému je třeba správně nastavit parametry, které právě zajistí dobře fungující systém. Jedná se především o dobu odchodu do starobního důchodu, nebo o minimální dobu pojištění či o stanovení př́slušných redukčních hranic a jejich výše, a tím identifikaci míry zásluhovosti. Klíčové je rovněž stanovení zdrojů, ze kterých bude důchodový systém financován, a s tím související vymezení přijatelné výše starobního důchodu ve vztahu např. k průměrné mzdě. Vhodné je vymezení tzv. státního důchodu na bázi nultého pilirire, který by byl financován z prríslušných daňových výnosů. Případné prodlužování věku odchodu do starobního důchodu je třeba řešit velmi obezřetně, protože prodlužování věku dožití ještě neznamená zvyšování schopnosti déle pracovat. Problematiku je možné řešit naopak podporou populační politiky a rodin s dětmi. Závěrem je možné konstatovat, že historický vývoj na území dnešní ČR vždy odrážel př́ílušnou politickou a ekonomickou situaci, ale i relativní vyspělost právního systému, a že je velmi obtížné nacházet optimální řešení, nebot' mnohdy spravedlivému právnímu řešení brání ekonomické limity, což se týká např. otázky zásluhovosti v penzijních systémech.

doc. JUDr. Ing. Milan Hrdý, Ph.D.

Právnická fakulta Univerzity Karlovy

Fakulta financí a účetnictví Vysoké školy ekonomické v Praze

hrdy@svse.cz 